\title{
Kajian Wayfinding dan Orientasi Ruang Ditinjau dari Aspek Desain Interior Pada Perpustakaan Umum di KotaYogyakarta
}

\author{
Danang Febriyantoko \\ Program Studi Desain Interior \\ Institut Seni Indonesia Yogyakarta \\ danangfebriyantoko.df@gmail.com
}

\begin{abstract}
Abstrak
Perpustakan sebagai jantung pendidikan merupakan fasilitas publik yang utama bagi kota Yogyakarta dalam upaya menghasilkan generasi dan sumber daya manusia yang gemar membaca pustaka serta meningkatkan budaya literasi di lingkungan masyarakat. Keberadaan perpustakaan umum di kota Yogyakarta yang setrategis sebagai pusat studi membutuhkan perhatian khusus diberbagai aspek, salah satunya aspek pelayanan pengetahuan yang mendukung seperti aspek desain interior. Aktifitas literasi dalam mencari sumber pustaka memerlukan desain wayfinding yang efektif dan efisien. Orientasi arah serta pola sirkulasi pengunjung terkait zonasi serta sistem penanda ruang merupakan salah satu parameter yang digunakan dalam mengkaji wayfinding desain interior perpustakaan.
\end{abstract}

Kata kunci: Perpustakaan Umum, Wayfinding, Orientasi Ruang, Desain Interior

\begin{abstract}
Library as the heart of education is the main public facility for the city of Yogyakarta in an effort to produce generations and human resources who like to read literature and improve literacy culture in the community. The existence of a public library in the city of Yogyakarta that is as strategic as a center of study requires special attention in various aspects, one of which is supporting aspects of knowledge services such as interior design aspects. Literacy activities in finding library sources require an effective and efficient wayfinding design. The orientation of the direction and pattern of visitor circulation related to zoning and the system of space markers are one of the parameters used in studying the library's wayfinding interior design.
\end{abstract}

Keywords: Public Library, Wayfinding, Space Orientation, Interior Design

\section{Pendahuluan}

Perkembangan ilmu pengetahuan disertai oleh percepatan teknologi informasi menuntut terciptanya masyarakat yang gemar membaca, mengingat begitu cepatnya informasi dapat disebar luaskan ke khalayak umum terlebih ketika semua dapat diakses melalui media internet tidak hanya dengan buku atau sumber pustaka lain. Pesatnya perkembangan teknologi dengan segala fiturfiturnya kerap membuat kita terlena untuk membuka sosial media dari pada membaca buku, akibatnya sumber pustaka seperti halnya buku-buku hanya tersimpan rapi di salah satu sudut perpustakaan.

Peningkatan kapasitas sumber daya manusia erat kaitanya dengan kemampuan literasi, termasuk dalam hal ini tingkat gemar mambaca. Secara lebih luas tingkat gemar membaca suatu masyarakat menjadi tolak ukur kemajuan sebuah bangsa. Dari data Perpustakaan Nasional tahun 2017 yang dikutip dari halaman CNN Indonesia (Priska Sari Pratiwi,CNN Indonesia, 2018) mengeindikasikan frekuensi membaca orang Indonesia rata-rata hanya tiga sampai empat kali per 
minggu, sementara jumlah buku yang dibaca rata-rata hanya lima hingga sembilan buku per tahun. Rendahnya minat baca pada masyarakat Indonesia merupakan hal yang memprihatinkan, menyiasati hal tersebut pemerintah seharusnya memperhatikan keberadaan perpustakaan. Salah satu strategi yang dapat dilakukan adalah membuat desain interior perpustakaan yang nyaman dengan dilengkapi oleh fasilitas serta koleksi sumber pustaka yang lengkap.

Yogyakarta dikenal sebagai kota pendidikan dan kota pelajar dengan beragamnya insan terpelajar yang datang dari beragam latar belakang daerah datang menuntut ilmu di kota ini. Sebagai kota pelajar tentunya pemerintah Kota Yogyakarta perlu melengkapi diri dengan fasilitas penunjang bagi pelajar, salah satu fasilitas vital bagi pelajar adalah perpustakaan. Ketersedian pengetahuan baik yang tercetak dan terekam menjadi sumber pembelajaran serta informasi valid bagi pelajar yang ditunjang dengan fasilitas-fasilitas lain yang mendukung sesuai dengan perkembangan zaman. Peran perpustakaan dewasa ini tidak hanya sebagai tempat menyediakan koleksi bahan pustaka namun juga sebagai pusat studi dan kegiatan literasi, aktifitas mencari, membaca, dan berdiskusi menjadi penting bagi keberadaan perpustakaan. Di kota pelajar ini terdapat beberapa perpustakaan yang telah berdiri dan memiliki karakteristik tersendiri berdasarkan koleksi serta fasilitasnya, diantaranya adalah perpustakaan Kota Yogyakarta, Grahatama Pustaka dan Jogja Library Center.

\section{Perpustakaan}

Perpustakaan Umum merupakan lembaga pendidikan bagi masyarakat umum dengan menyediakan berbagai informasi, ilmu pengetahuan, teknologi dan budaya sebagai sumber belajar untuk memperoleh dan meningkatkan ilmu pengetahuan bagi seluruh lapisan masyarakat (Soetimah, 1992). Berdasarkan Undang-Undang no 43 Tahun 2007 mengenai perpustakaan, dijelaskan pada pasal 3 dan 4 dijelaskan mengenai fungsi dan tujuan perpustakaan, diantaranya adalah perpustakaan berfungsi sebagai wahana pendidikan, penelitian, pelestarian dan informasi dan rekreasi untuk meningkatkan kecerdasan dan keberdayaan bangsa. Sedangkan tujuan didirikan perpustakaan adalah memberikan layanan kepada pemustaka, meningkatkan kegemaran membaca serta memperluas wawasan dan pengetahuan untuk mencerdaskan kehidupan bangsa. Terdapat 4 aspek yang perlu diperhatikan dalam penataan ruang perpustakaan, aspek-aspek, yaitu: aspek fungsional, aspek psikologis pengguna, aspek estetika, dan aspek keamanan bahan pustaka. Ketika aspek-aspek penataan ruang perpustakaan tersebut mampu diterapkan mengikuti hakikatnya dengan baik, maka perpustakaan pasti dapat menjadi tempat yang sangat kondusif sebagai penyimpan koleksi referensi dan informasi (Sutarno, 2006)

Seiring dengan perkembangan teknologi dan informasi, koleksi pada perpustakaan tidak hanya berupa buku cetak namun juga media baru untuk menyimpan informasi yang bermanfaat bagi pengetahuan seperti audio dan video. Perpustakaan masa kini juga merupakan tempat penyimpanan soft file dan atau akses ke map, cetak atau hasil seni lainnya, mikrofilm, mikrofiche, tape audio, CD, LP, tape video dan DVD, serta menyediakan fasilitas umum untuk mengakses gudang data CD-ROM dan internet. Dampak dari perkembangan teknologi informasi tersebut keberadaan perpustakaan harus turut mengikuti perkembangan teknologi, sehingga diperlukan sarana dan prasarana yang menunjang penyimpanan informasi tersebut.

Fungsi umum perpustakaan adalah bersifat edukatif, informatif, rekreatif, dan riset atau penelitian. Bahkan apabila dapat dikembangkan lagi, fungsi perpustakaan secara khusus ialah sebagai pusat kebudayaan bangsa, pusat kegiatan sosial, dan pusat informasi. Dalam tugasnya sehari-hari perpustakaan lebih banyak melayani orang-orang yang bertanya tentang informasi yang ada di perpustakaan, baik secara langsung kepada pustakawan yang sedang bertugas ataupun mencari bahan bacaan melalui katalog. Fungsi informatif lebih menekankan perpustakaan sebagai tempat bertanya bersifat sedia menjawab pertanyaan masyarakat akan segala macam informasi yang dibutuhkan. Fungsi edukatif, artinya isi atau koleksi yang ada disiapkan dan di sediakan oleh perpustakaan bersifat mendidik. Sedangkan fungsi rekreatif dan riset merupakan fungsi yang 
minoritas, sehingga orang jarang akan pergi ke perpustakaan karena kedua fungsi tersebut. Fungsi perpustakaan secara umum meliputi banyak bidang yang antara lain pendidikan, informasi, kebudayaan, pelestarian, dan rekreasi (Haryanto, 1998)

- Fungsi Informasi

Fungsi ini bekerja ketika masyarakat sebagai pemakai jasa perpustakaan membutuhkan informasi. Informasi yang dimaksud mencakup berbagai hal dan dapat diakses melalui perpustakaan.

- Fungsi Pendidikan.

Perpustakaan tidak sekedar menjadi tempat membaca namun juga menjadi salah satu media pencerdasan bangsa. Melalui koleksi perpustakaan, masyarakat mendapat banyak pengetahuan.

- Fungsi Pelestarian

Disisi lain perpustakaan juga berperan sebagai salah satu media penyelamat bukti-bukti sejarah. Banyak dokumen-dokumen sejarah yang baik secara langsung maupun tidak langsung terselamatkan dengan adanya perpustakaan. Disinilah perpustakaan dengan fungsi pelestariannya berperan.

- Fungsi Kebudayaan (Kultural)

Perpustakaan bisa berfungsi sebagai media publikasi kebudayaan tempat dimana perpustakaan berada. Wisatawan dan masyarakat luas bisa mengetahui kebudayaan setempat melalui berbagai koleksi perpustakaan.

- Fungsi Rekreasi

Fungsi ini dapat berjalan optimal jika sistem pengelolaan perpustakaan diarahkan pada aktifitas yang inovatif sehingga perpustakaan tidak dipandang sebagai sebuah bangunan yang membosankan. Artinya bila perpustakaan dapat memberikan sesuatu yang lebih dari sekedar infomasi tetapi juga menyediakan layanan yang bersifat "entertaining" maka orang tentu akan lebih tertarik untuk mengunjungi perpustakaan tersebut.

Sesuai dengan unsur pengertian bahwa di dalam perpustakaan terdapat koleksi yang digunakan untuk keperluan studi, penelitian, bacaan umum, dan lainnya, maka perpustakaan pelbagi macam tujuan (Qalyubi, 2007):

- Sebagai sumber ilmu pengetahuan (intelektual)

- Sebagai sumber untuk bisa mendapatkan ilmu pengetahuan dengan mudah dan hemat biaya (ekonomis)

- Sebagai alat penghubung antar generasi (sosial)

- Sebagai tempat pemeliharaan berbagai barang-barang bernilai hasil budaya manusia (kultural).

- Sebagai barometer/tolak ukur untuk melihat dan mengetahui bagaimana tingkat kemajuan, kecerdasan, dan peradaban suatu bangsa.

- Tempat rekreasi yang murah, hemat, dan mendidik dengan koleksi buku-buku yang menarik

Tujuan pada perpustakaan secara umum ialah memberikan pelayanan kepada masyarakat umum akan kebutuhan informasi, rekreasi, pendidikan dan kebudayaan, serta barometer bagi tingkat kecerdasan, kemajuan, peradaban suatu bangsa melalui penyediaan bahan-bahan tercetak dan bahan lain yang bermanfaat sebagai bahan bacaan. Setiap perpustakaan dapat mempertahankan eksistensinya apabila dapat menjalankan peranan yang baik dan benar. Secara umum peran-peran yang dapat dilakukan oleh perpustakaan adalah (Nugraha, 2013):

- Menjadi media antara pemakai dengan koleksi sebagai sumber informasi pengetahuan

- Menjadi lembaga pengembangan minat dan budaya membaca serta pembangkit kesadaran pentingnya belajar sepanjang hayat

- Mengembangkan komunikasi antara pemakai dan atau dengan penyelenggara sehingga tercipta kolaborasi, sharing pengetahuan maupun komunikasi ilmiah lainnya 
- Motivator, mediator dan fasilitator bagi pemakai dalam usaha mencari, memanfaatkan dan mengembangkan ilmu pengetahuan dan pengalaman. Berperan sebagai agen perubah, pembangunan dan kebudayaan manusia

\section{Wayfinding}

Wayfinding dapat dididefinisikan sebagai kemampuan untuk menemukan jalan menuju suatu lokasi. Sedangkan Spatial Orientation adalah kemampuan seorang individu untuk memahami ruang di sekitarnya dan meletakkan dirinya. Seringkali individu tidak dapat menentukan posisinya dalam lingkungan tetapi dapat menemukan jalan ke sebuah lokasi, sehingga individu tetap berorientasi pada lingkungannya (Passini, 1984) Istilah wayfinding pertamakali digunakan oleh seorang arsitek Kevin Lynch di tahun 1960 (Lynch, 1960) ketika ia menyebut peta, nomer jalan, petunjuk arah, dan elemen lain sebagai alat atau cara dalam menemukan jalan. Kata wayfinding sendiri tidak dapat ditemukan dalam kamus standard bahasa Inggris, namun karena penggunaanya banyak muncul dalam literature psikologi lingkungan, geografi, dan psikologi kognitif.

Menurut (G.Golledge, 2010) wayfinding merupakan proses menentukan jalan atau rute antara titik awal dan tujuan. Wayfinding merupakan aktifitas yang terarah, memiliki tujuan, dan dilatarbelakangi oleh motivasi dan dapat dilihat sebagai bukti dari tindakan sensorimotor dalam lingkungan. Wayfinding merujuk pada suatu gerakan yang memiliki tujuan ke suatu tempat yang spesifik yang jauh atau berjarak dan tidak dapat dibayangkan secara langsung oleh pelakunya. Wayfinding adalah istilah yang digunakan untuk menggambarkan pengalaman dan persepsi pengguna dalam suatu konteks lingkungan di mana salah penanganan menyebabkan disorientasi dan kebingungan (Abrams, 2010). Wayfinding adalah proses pengumpulan informasi dan pengambilan keputusan yang digunakan orang untuk mengarahkan diri mereka dan bergerak melalui ruang, bagaimana orang berpindah dari satu tempat ke tempat lain (Hunter, 2010) Wayfinding merupakan proses bergerak dari lokasi saat ini ke tujuan yang diinginkan secara tepat. Manusia telah berhasil melakukan proses ini dengan menggunakan berbagai cara.

Berkaitan dengan efisienitas penggunaanya, wayfinding juga berfungsi adaptif, yang memungkinkan penggunanya bergerak secara efisien untuk mendapatkan hal-hal penting yang diinginkannya, seperti makan, tempat tinggal, atau titik kumpul atau pertemuan yang telah direncanakan dalam suatu lingkungan. Tujuan utama dari wayfinding adalah menemukan jalan yang akurat dari satu tempat ke tempat lain, secara umum dapat didefinisikan bahwa wayfinding adalah prilaku bergerak dari suatu tempat ke tempat lainnya baik yang sudah diketahui maupun belum diketahui, dimana prilaku tersebut didasari oleh motivasi, perencanaan, memiliki tujuan, dan diupayakan dengan cara yang efisien.

Teori wayfinding didasari oleh beberapa fakta dimana banyak orang yang mengalami kesulitan untuk menemukan arah dalam sebuah lokasi yang umumnya baru mereka ketahui. Kehilangan orientasi atau bahkan ketersesatan dapat terjadi dalam proses menemukan jalan, yang umumnya disebabkan oleh rumitnya tata ruang dalam sebuah kondisi lingkungan banguanan sehingga membutuhkan kejelian dalam mendesain lingkungan binaan dan menempatkan atau menciptakan penanda yang baik untuk menunjukan informasi yang ingin disampaikan. Wayfinding merupakan sebuah proses dalam memaksimalkan unsur yang terdapat dalam sebuah bangunan atau ruang publik sehingga pengunjung dapat dengan mudah menemukan tujuan yang dimaksud. Misalnya pada stasiun, museum atau bandara sebuah informasi yang diwujudkan dari keberadaan signage akan membantu pengunjung menghadirkan suasana yang nyaman dan aman, serta mengefiensikan waktu dan mamandu pengunjung atau penumpang yang akan menggunakan sarana publik tersebut. Kemampuan wayfinding atau mengorientasikan diri terhadap lingkungannya sangat dibutuhkan oleh manusia agar dapat bergerak secara efektif. Kemampuan untuk mengorientasikan diri baik secara sosial maupun fisik mempengaruhi rasa aman seseorang.

Dalam penciptaan ruang dalam dibutuhkan sebuah strategi yang didalamnya terdapat beberapa syarat / pendekatan yang dilakukan yang didasarkan pendekatan ruang, kegunaan dan kesesuaian 
dengan tapak atau lingkungan yang ada. Beberapa hal yang menjadi perhatian khusus ketika mendesain ruang dalam adalah dengan memperhatikan bentuk-bentuk dan ukuran ruang yang meliputi elemen pembentuk ruang, pengguna ruang dan berapa lama seseorang berada di dalamnya, serta kontrol lingkungan atau tata kondisional. Hal-hal tersebut secara implisit dan eksplisit berpengaruh dalam mengekspresikan tatanan ruang yang berkualitas, hubungan antar ruang, pengguna dan elemen-elemennya menjadi dasar bagi hirarki yang akan diekspresikan dalam bangunan. Fasilitas-fasilitas dalam ruang juga dirancang sesuai dengan aksesibilitas pengguna yang ada agar dapat digunakan dengan baik seefektif mungkin.

Orientasi dalam sebuah bangunan erat kaitannya dengan keadaan lingkungan alam tempat bangunan tersebut didirikan, hal ini berkaitan dengan arah hadap bangunan, mata angin, alur sirkulasi udara, pencahayaan matahari, dan lain sebagainya. Kesadaran akan lingkungan sekitar sangat dibutuhkan oleh desainer untuk menentukan peletakan bangunan selain sebagai wadah aktifitas penggunanya juga akan memiliki fungsi sebagai penanda sumber informasi visual yang mudah diingat dalam membantu proses kognitif pada sistem wayfinding.

Keberadaan beberapa perpustakaan di kota Yogyakarta yang strategis sebagai pusat studi membutuhkan perhatian diberbagai aspek pelayanan pengetahuan, salah satunya adalah aspek interior bangunanya sendiri. Interior perpustakaan yang mendukung aktifitas literasi menjadi perhatian khusus. Kegiatan belajar, berdiskusi serta mencari bahan informasi membutuhkan fasilitas yang mudah dijangkau baik secara aksesibilitas maupun kenyamananya. Berbagai elemen desain interior di dalam perpustakaan dapat menjadi pedoman atau panduan bagi pengunjung dalam menentukan arah dan menelusiri sumber pustaka, seperti keberadaan landmark atau penanda khusus yang dijadikan patokan berorientasi di lingkungan perpustakaan. Diperlukan kajian lebih mendalam terhadap sistem wayfinding dan orientasi ruang mengenai bagaimana pengguna ruang perpustakaan dapat menemukan ruang maupun sumber pustaka yang dicari.

\section{Metode}

Kajian wayfinding dan orientasi ruang pada perpustakaan umum menggunakan metode wayfinding dikutip dari Passini $(1984 ; 185)$ yang terdiri dari 7 tahapan proses wayfinding :

- Wayfinding Task

Pada tahapan ini akan dijelaskan bagaimana tujuan dari destinasi yang telah disepakati dengan menetapkan tujuan awal yang diawali dengan pengelompokan berdasarkan zona destinasi

- User profile

Menganalisa profil pengguna perpustakaan untuk mengetahui tingkat pengetahuan pengguna secara umum, permasalah aksesbilitas, dan proses pengelolaan informasi lingkungan

- Wayfinding condition

Mengetahui tingkat kesulitan mencari jalan untuk melihat efektifitas sistem yang telah ada, melihat kekayaan pegetahuan dalam menemukan jalan serta melihat suasana yang diperlukan oleh setiap tujuan destinasi.

- Design requirements

Menganalisa kebutuhan desain untuk mengetahui spesifikasi desain berdasarkan kombinasi tujuan serta kebiasaan pengguna ruang.

- Wayfinding solution

Menyusun sebuah sistem wayfinding yang terintegrasi dengan pengadaan sistem informasi yang mendukung proses pengambilan keputusan

- Suportive information

Mengumulkan detail informasi yang diperlukan untuk setiap alternatif konsep yang dihasilkan. Hal ini dilakukan dengan merencanakan elemen spasial dan sistem grafis, serta identifikasi lingkungan.

- Design Solution 
Menyususn sebuah desain wayfinding untuk bangunan perpustakaan beserta sistem grafis lingkungan dengan memperhatikan seluruh jalur kegiatan pada sistem aksesibilitas utama

Kajian ini secara geografis akan dilaksanakan pada perpustakaan umum yang terdapat di kota Yogyakarta, Dari data perpustakaan umum yang tersebar di kota Yogyakarta dipilih tiga perpustakan sebagai sample atau studi kasus

a. Perpustakaan Kota Yogyakarta, Jl Suroto no 9, Kota Baru Yogyakarta

b. Grahatama Pustaka, Jl Janti Wonocatur, Banguntapan Yogyakarta

c. Jogja Library Center, Jl. Malioboro 175, Sosromeduran Yogyakarta

Pemilihan ketiga perpustakaan tersebut sebagai sample atau studi kasus penelitian dengan mempertimbangkan karakter, fasilitas serta kebutuhan ruangnya. Variabel dalam penelitian adalah elemen interior perpustakaan, dapat meliputi elemen pembentuk ruang, elem pengisi ruang dan tata kondisional yang dapat membantu pengunjung dalam mengidentifikasi, mencari dan menjelajahi ruang perpustakaan. Dalam penelitian ini akan diketahui bagaimana pengunjung perpustakaan melakukan adaptasi terhadap kondisi layout perpustakaan dalam aktivitasnya diperpustakaan seperti mencari sumber pustaka, berdiskusi, atau menggunakan fasilitas-fasilitas lain yang ada di perpustakaan.

Metode yang digunakan adalah metode analisis kualitatif yang bersifat induktif, yakni metode yang menggunakan uraian, paparan, dan gambaran mengenai data primer, yaitu data yang diperoleh langsung dari peneliti kepada sumbernya. Sifat induktif yaitu pengembangan konsep yang didasarkan atas data yang ada, mengikuti desain penelitian yang fleksibel sesuai dengan konteksnya. Desain dimaksud tidak kaku sifatnya sehingga memberi peluang kepada peneliti untuk menyesuaikan diri dengan konteks yang ada di lapangan.

\section{Pembahasan}

\section{A. Grahatama Pustaka}

Grahatama Pustaka merupakan sebuah learning center yang dirancang untuk memenuhi kebutuhan pendidikan, penelitian, pelestarian, informasi dan rekreasi bagi masyarakat luas. Grahatama pustaka didirikan pada 21 Desember 2016, menempati bangunan baru yang didesain modern termasuk dalam kategori perpustakaan terbesar di Indonesia dengan luas lahan 2,4 hektar. Perpustakaan yang memiliki tiga lantai ini berlokasi di jalan Janti Banguntapan Bantul, memiliki berbagai koleksi pustaka dan fasilitas yang cukup lengkap ditujukan bagi masyarakat umum sebagai alternatif perpustakaan serta wisata edukasi di kota Yogyakarta.

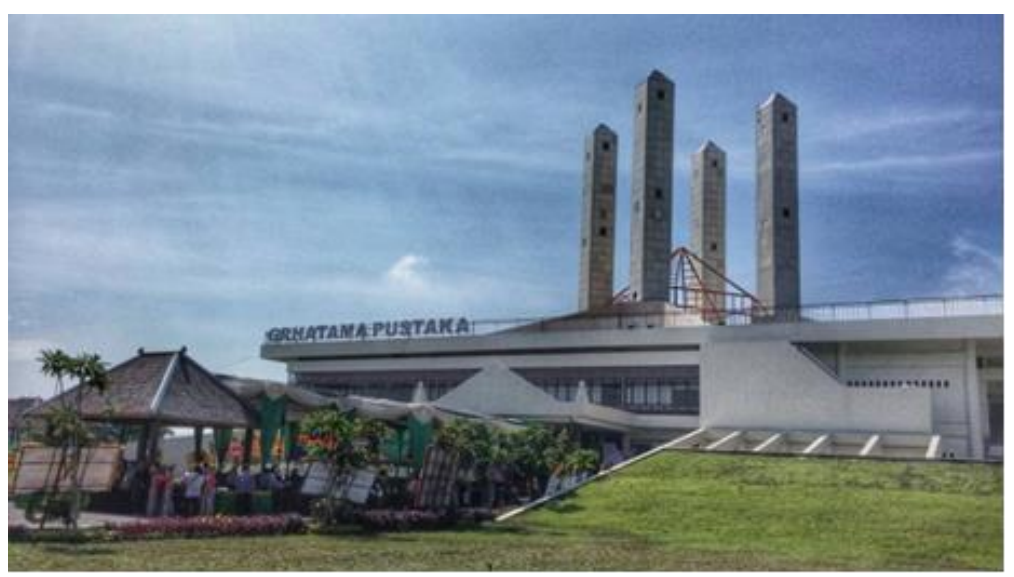

Gambar 1. Grahatama Pustaka Sumber: BPAD DIY 
Tabel 1 Wayfinding Grahatama Pustaka

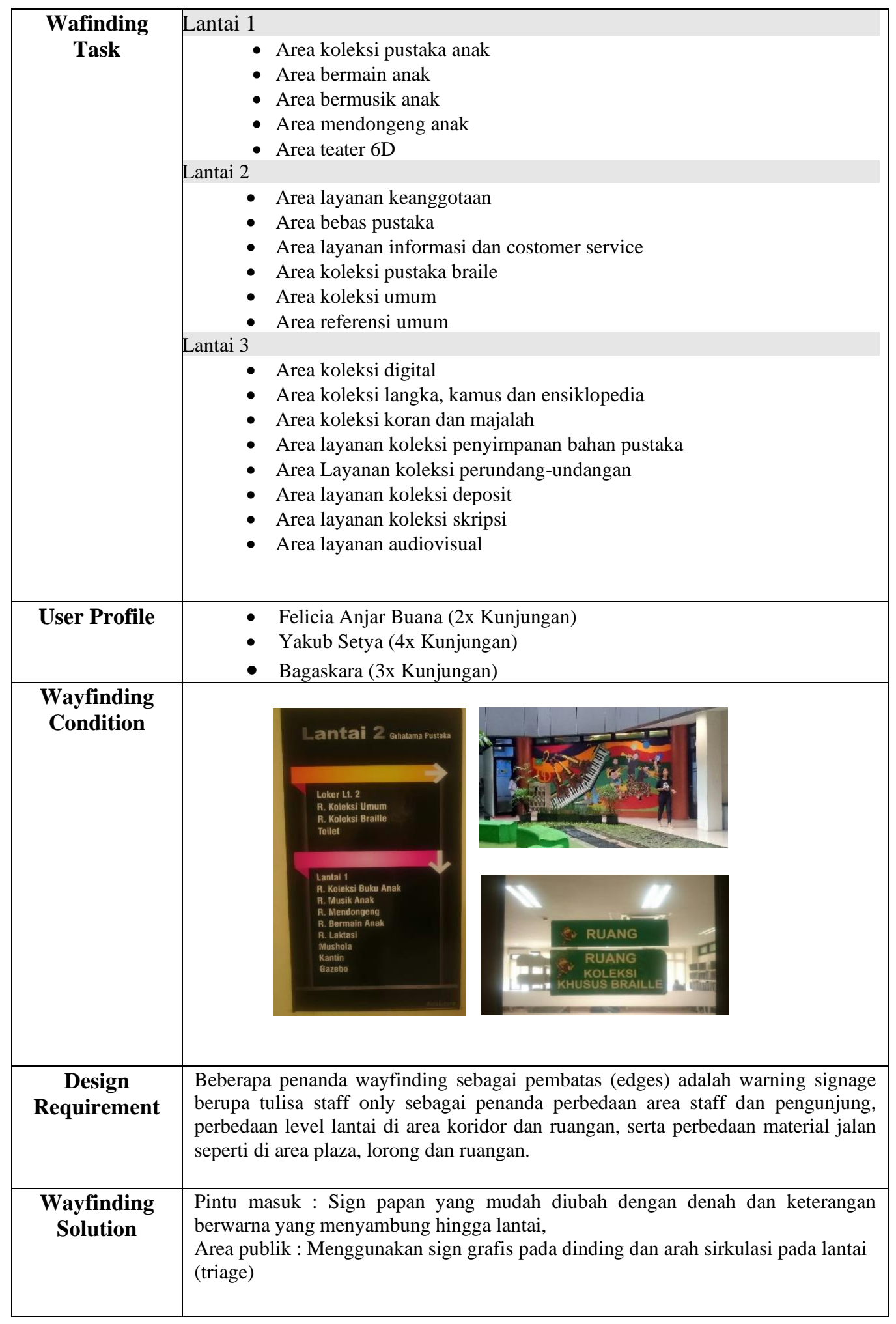




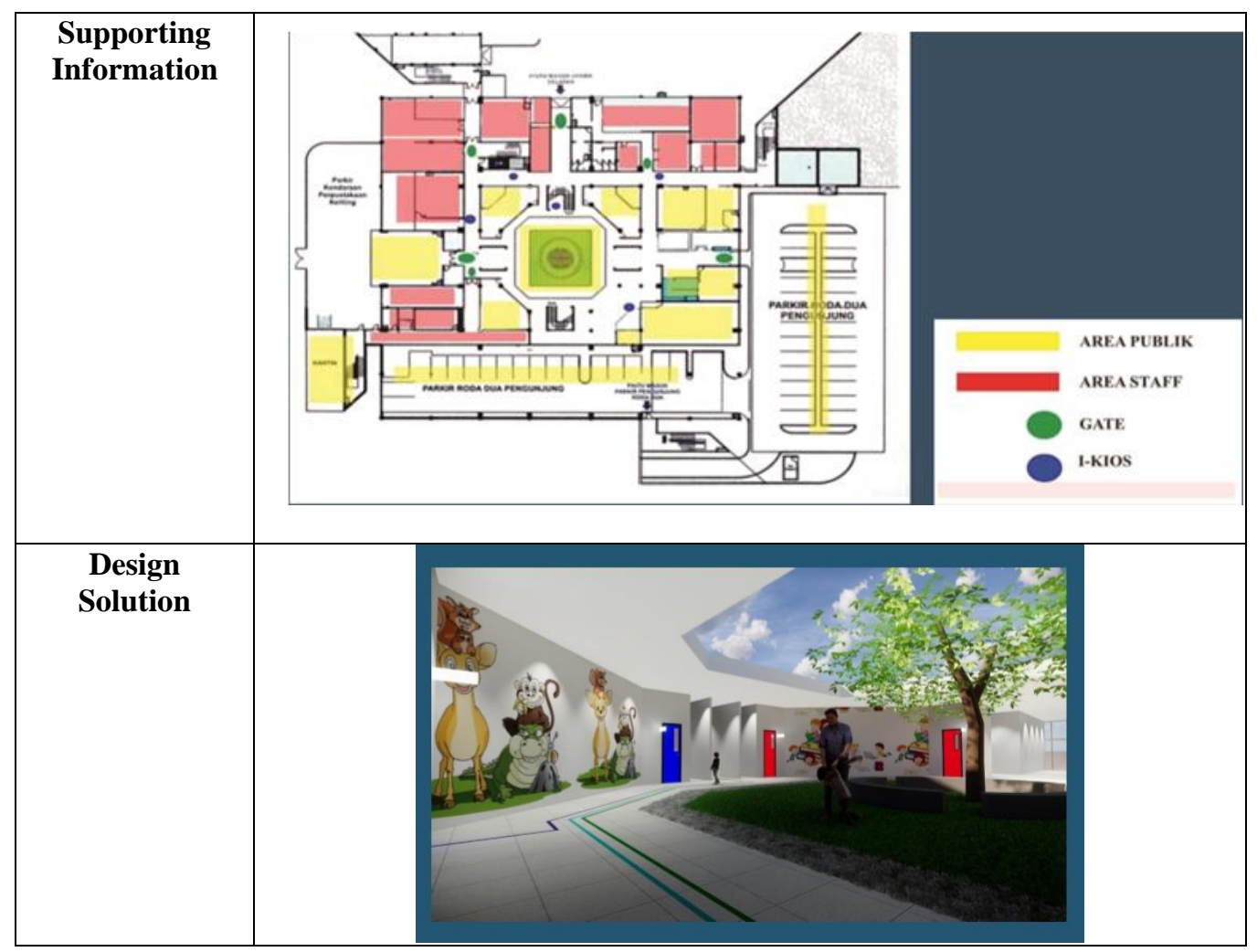

\section{B. Perpustakaan Kota Yogyakarta}

Perpustakaan Kota Yogyakarta berdiri sejak 2 Mei 1993 yang pertama kali dirintis dan dikelola oleh cabang Dinas Pendidikan dan Kebudayaan Kotamadya Yogyakarta, awalnya perpustakaan ini berada di jalan Pekapalan alun-alun utara, meskipun lokasinya strategis namun tempat ini kurang dikenal oleh masyarakat. Akhirnya pada 20 Juli 2007 UPT perpustakaan menempati gedung baru di jalan Suroto Kota Baru, menempati bangunan dua lantai seluas 600 meter persegi ternyata mendapat sambutan yang cukup baik dari masyarakat ditandai dengan meningkatnya jumlah kunjungan pustakawan, diikuti dengan peningkatan fasilitas serta diversifikasi jenis layanan. Lokasinya yang strategis di pusat kota sehingga mudah diakses dari berbagai institusi pendidikan menjadikan perpustakan kota Yogyakarta menjadi salah satu tempat alternatif bagi insan akademik dalam memenuhi kebutuhan intelektualnya.

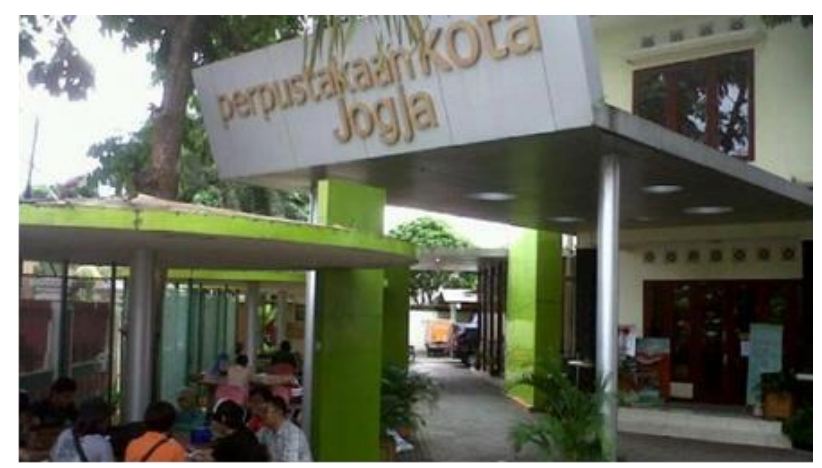

Gambar 2. Perpustakaan Kota Jogja

Sumber : jogja.tribunnews.com 
Tabel 2. Wayfinding Perpustakaan Kota Yogyakarta

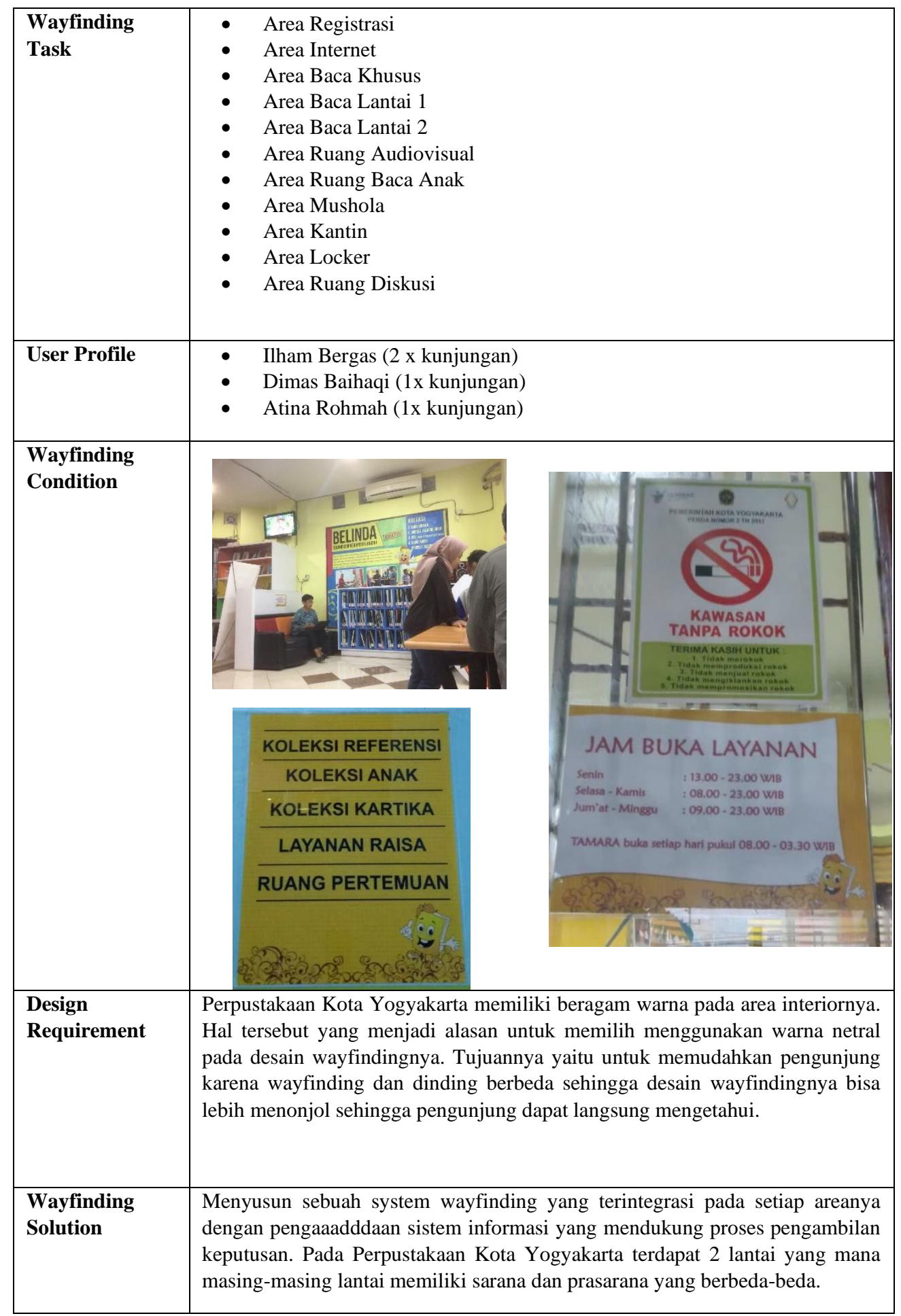




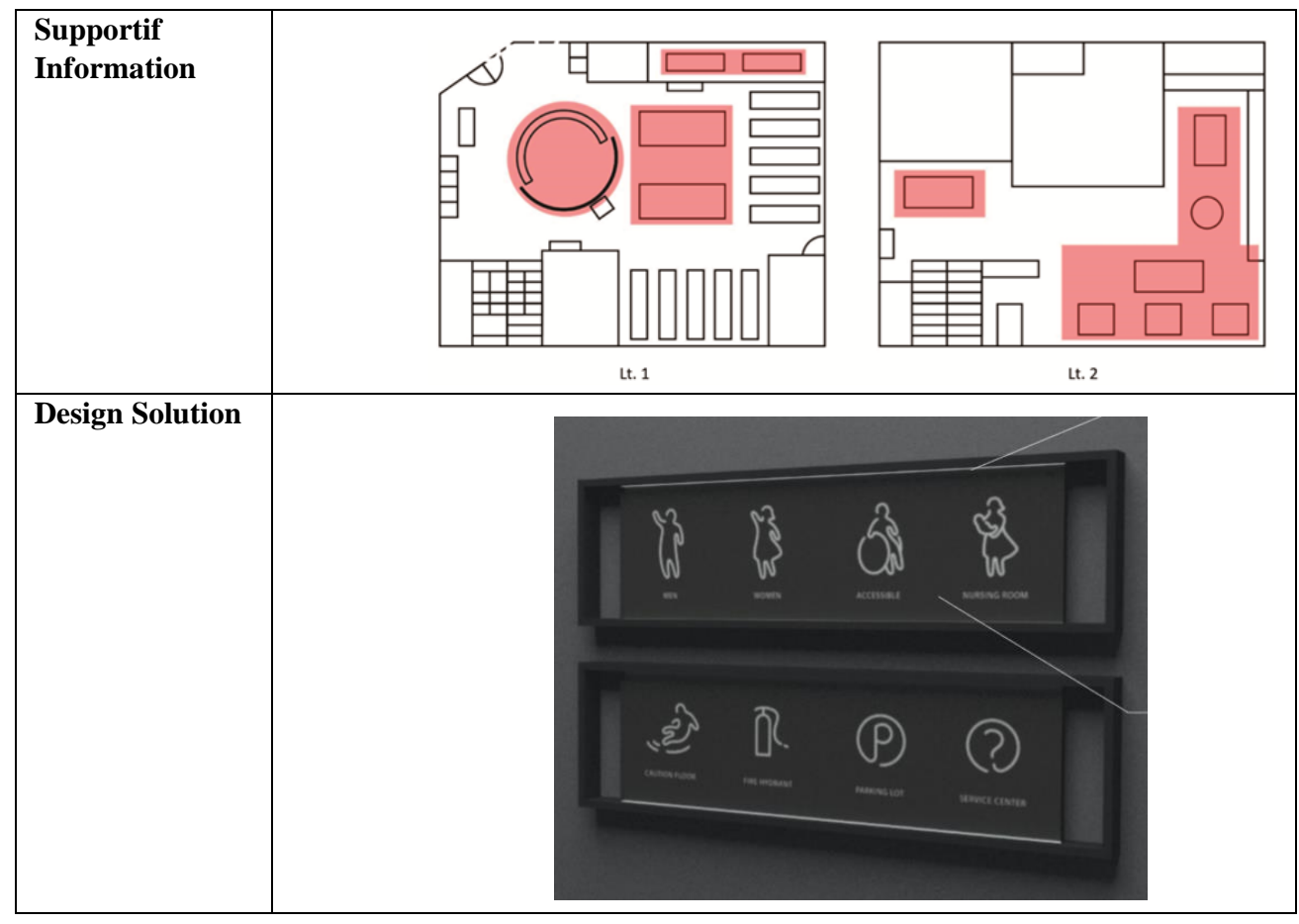

\section{Jogja Library Center}

Jogja Library Center merupakan jenis perpustakaan yang mengusung tema sejarah, dengan koleksi pustaka langka dan kuno menjadikan perpustakaan ini berbeda dengan perpustakaan lain. Sistem layanan yang digunakan hanyalah membaca ditempat sehingga pengunjung tidak diperkenankan untuk meminjam koleksi. Berada di pusat bisnis kota Yogyakarta, keberadaan Jogja Library Center seperti terasing ditengah keramaian jalan Malioboro. Menempati bangunan kuno dua lantai perpustakaan ini termasuk kategori perpustakaan dan arsip tertua di Indonesia yang sudah berdiri sejak 17 Maret 1952. Perpustakaan ini menyatu dengan deretan ruko sehingga tidak banyak orang mengetahui ada perpustakaan di Malioboro. Pengunjung yang datang tidak terlalu banyak umumnya masyarakat yang sekedar untuk membaca koran, koleksi pustaka kuno maupun pelajar yang sekedar belajar dan berdiskusi. 


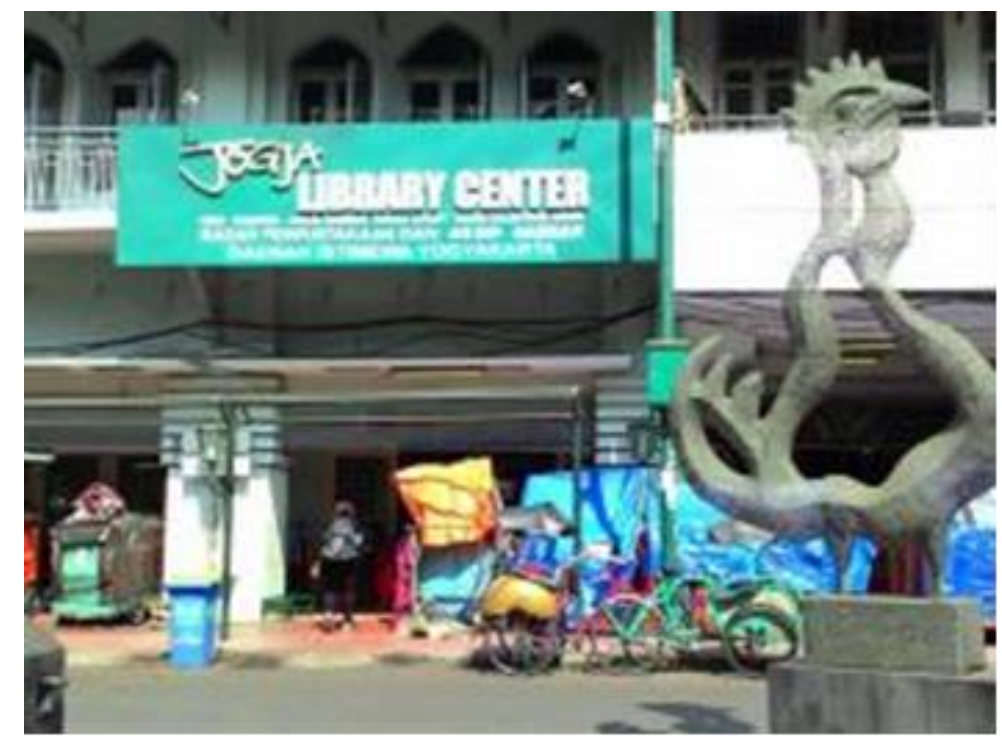

Gambar 3. Jogja Library Center

Sumber: BAPPEDA DIY

Tabel 3. Wayfinding Jogja Library Center

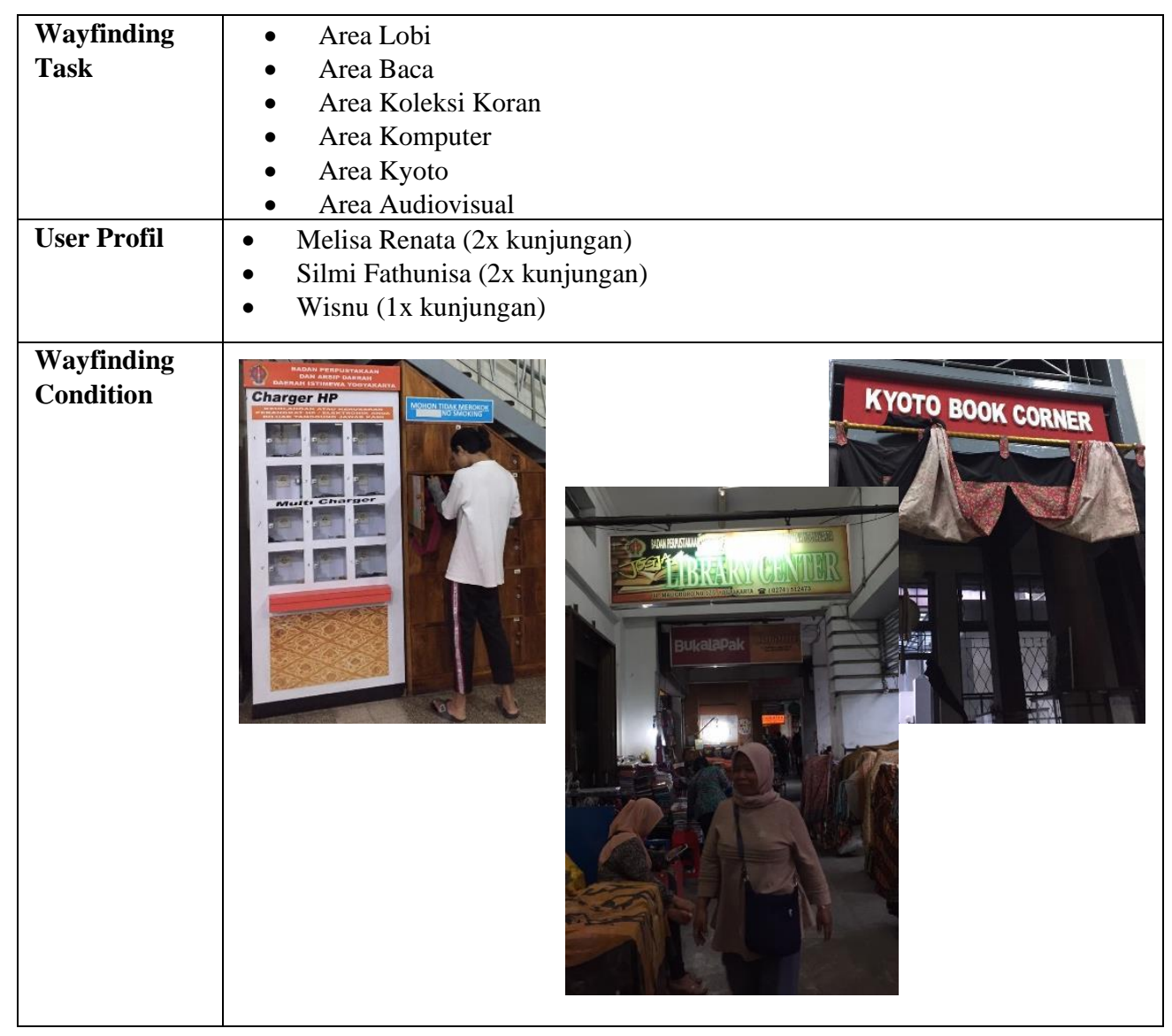




\begin{tabular}{|c|c|}
\hline $\begin{array}{l}\text { Design } \\
\text { Requirement }\end{array}$ & $\begin{array}{l}\text { Jogja Library Center dengan luas bangunan yang tidak terlalu besar dan berada di } \\
\text { pusat perbelnjaan memerlukan desain wayfinding yang lebih mudah dikenal. } \\
\text { Sistem penanda bangunan yang tersamarkan oleh kios-kios perbelanjaan } \\
\text { merupakan salah satu tantangan desain yang akan dihadapi, selain itu koleksi } \\
\text { pustaka yang umumnya berupa naskah-naskah kuno memerlukan treatment } \\
\text { khusus dalam akomidasi penyimpanan serta tata letak layoutnya. }\end{array}$ \\
\hline $\begin{array}{l}\text { Wayfinding } \\
\text { Solution }\end{array}$ & $\begin{array}{l}\text { Memperbaiki hirarki bangunan sehingga pola sirkulasi pengunjung lebih } \\
\text { terorganisir dengan baik mengingat bangunan perpustakaan yang tidak terlalu } \\
\text { luas memerlukan strategi pengorganisasian ruang yang efektif }\end{array}$ \\
\hline $\begin{array}{l}\text { Suportif } \\
\text { Information }\end{array}$ & $\begin{array}{l}\text { Standing } \\
\text { Tempel } \\
\text { Gantung }\end{array}$ \\
\hline $\begin{array}{l}\text { Design } \\
\text { Solution }\end{array}$ & 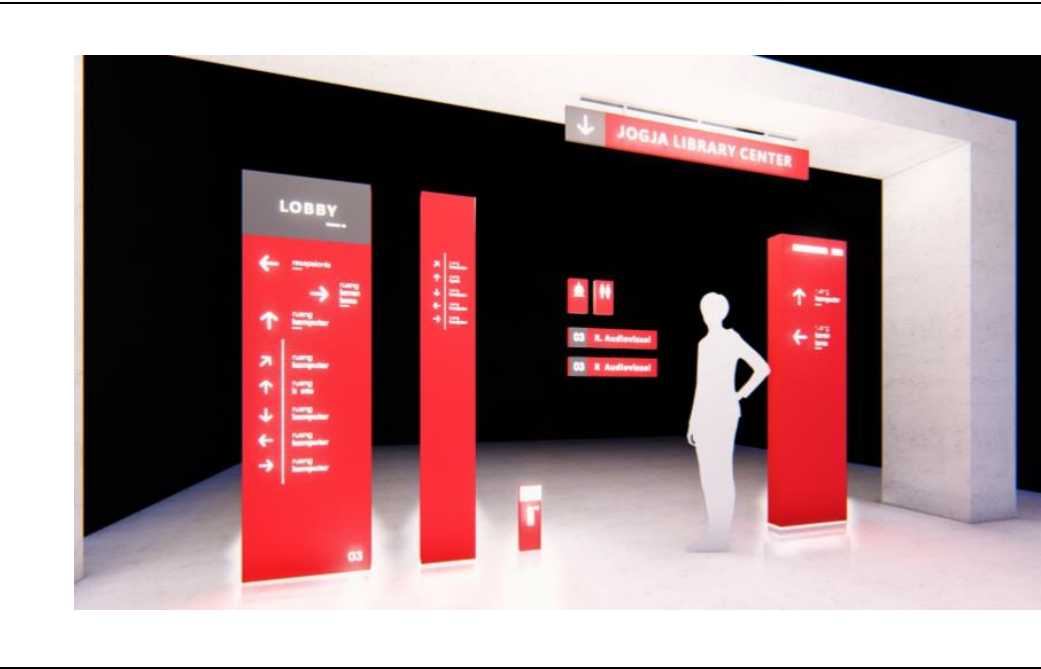 \\
\hline
\end{tabular}

\section{Simpulan}

Berdasarkan dari hasil analisis menunjukkan bahwa terdapat beberapa obyek elemen desain interior yang dapat dijadikan penanda ruang bagi pengembangan sistem wayfinding di perperpustakaan umum. Beberapa elemen desain tersebut meliputi elemen pembentuk ruang (lantai, dinding dan ceiling) maupun elemen pengisi ruang seperti furniture terkait tata letak / layout pelayanan perpustakaan umum di kota Yogyakarta. Selain elemen desain aspek desain interior lain yang turut mempengaruhi wayfinding dan orientasi ruang adalah faktor ambience atau suasana ruang yang dihadirkan. Fungsi perpustakaan umum sebagai pusat informasi, pendidikan, 
pelestarian, kebudayaan dan rekreasi turut mempengaruhi suasana ruang yang ingin ditunjukan pada ketiga perpustakaan sample.

Pada perpustakaan Grahatama Pustaka, fungsi pusat informasi dan rekreasi lebih dikedepankan yang didukung oleh sarana prasarananya. Pengunjung yang datang pun lebih banyak merupakan kalangan umum yang datang untuk berekreasi pengetahuan denagn koleksi pustaka umum.

Pada perpustakaan Kota Yogyakarta, fungsi pusat pendidikan dan informasi ditandai dengan dominasi pengunjung yang merupakan pelajar. Sarana dan prasarana di perpustakaan kota Yogyakarta juga didominasi dengan kegiatan berkumpul dan berdiskusi bagi pelajar.

Pada Jogja Library Center, fungsi pelestarian dan kebudayaan merupakan suasana ruang yang lebih dominan, dengan koleksi pustaka naskah kuno yang didukung oleh sarana dan prasarana yang mendukung pengembangan ilmu sejarah bagi kota Yogyakarta

\section{DAFTAR PUSTAKA}

Abrams, J. (2010). Wayfinding in Architecture. University of South Florida.

G.Golledge, R. (2010). Wayfinding Behavior: Cognitive Mapping and Other Spatial Processes 1st Edition.

Haryanto, R. (1998). Perpustakaan dan Aturannya. Jakarta: PT. Budi Santosa.

Hunter, S. (2010). Spatial Orientation, Environmental Perception and Wayfinding. New York: University at Buffalo.

Lynch, K. (1960). The Image Of The City. Cambridge: The MIT Press.

Nugraha, H. (2013). PERPUSTAKAAN DAN PELESTARIAN KEBUDAYAAN. Jural Perpustakaan Vol 4 No 1, 50-61.

Passini, R. (1984). Wayfinding in Architecture. Environmental Design . New York: Van Nostrand Reinhold.

Priska Sari Pratiwi,CNN Indonesia. (2018, Maret 27). Minat Baca Masyarakat Indonesia Masih Rendah. Retrieved juli 20, 2019, from https://www.cnnindonesia.com: https://www.cnnindonesia.com/gaya-hidup/20180326160959-282-285982/minat-bacamasyarakat-indonesia-masih-rendah

Qalyubi, S. (2007). Dasar-dasar Ilmu Perpustakaan dan Informasi,. Yogyakarta: Jurusan Ilmu Perpustakaan dan Informasi Fakultas Adab UIN Yogyakarta.

Soetimah. (1992). Perpustakaan, Kepustakaan dan Pustakawan. Yogyakarta: Kanisius.

Sutarno. (2006). Manajemen Perpustakaan; suatu pendekataan praktik. Jakarta: Sagung Seto.

Undang-Undang Republik Indonesia Nomer 43 Tentang Perpustakaan 